\title{
LIVER FUNCTION TESTS IN DAIRY COWS WITH FATTY LIVER INDUCED BY PRIMARY KETOSIS
}

\section{ABSTRACT}

Received at: 6/5/2012

Accepted:
The aim of the present study is to shed light on the evaluation of biochemical parameters of liver function in case of affection by fatty liver induced by primary ketosis, graduation of this disease depending on biochemical parameters into three degrees (severe, moderate and mild) treatment of some cows in different degrees of the disease was carried out depending on the changes of the histological liver investigation and detection of fat deposition in hepatic cells. The measured biochemical parameters were (glucose, urea, total protein, albumin, globulin, bilirubin, AST, GGT and CPK). The result revealed a significant increase in estimated enzymes (AST, GGT and CK) there were also in both severe and moderate groups when compared with the control cows, Also a significant decrease in albumin concentration in case of severe and moderate groups when compared with the control cows in addition result revealed a significant increase of BHBA in blood serum of diseased cows compared with control cows. In conclusion it was obvious that liver function tests (AST, GGT, CK, albumin and BHBA) have an important role in diagnosis of fatty liver in case of dairy cows as they showed a clear difference between affection levels and healthy cows (control).

\section{اختبارات وظائف الكبد في الأبقار الحلوب المتأثرة بالتشحم الكبدي الناتج عن الكيتوزس الأولي}

\section{عماد عبدالعزيز خلف ، نزار عدي}

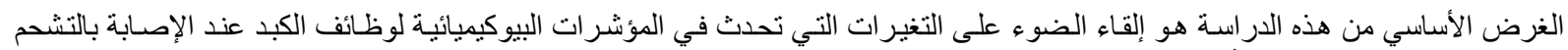

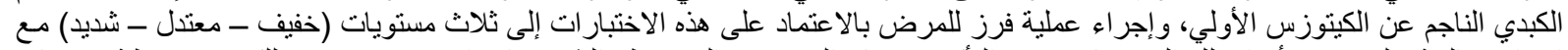

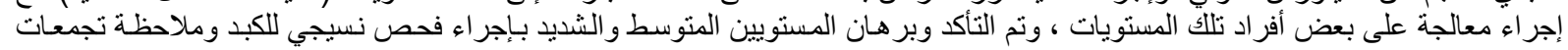

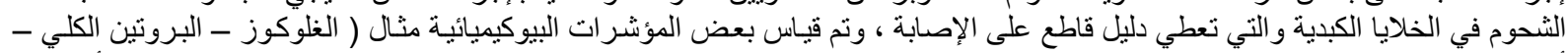

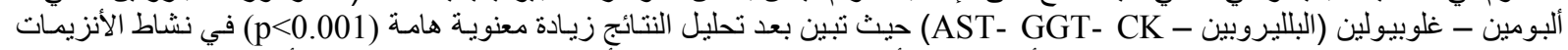

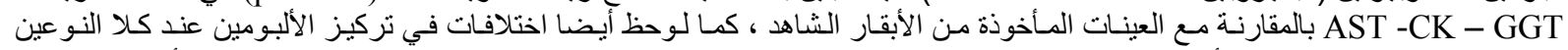

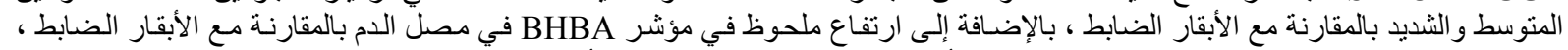

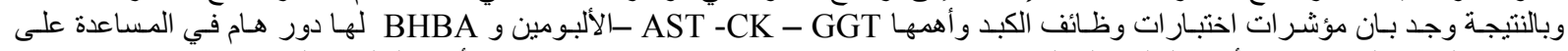
تشخيص التشحم الكبدي عند الأبقار الحلوب لما لها من اختلافات واضدة واضنة بين مستويات الإصابة وبين الأبقار السليمة (الضابطة)

\section{Key words:}

\section{INTRODUCTION \\ المقدمسة}

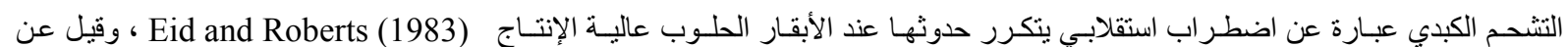

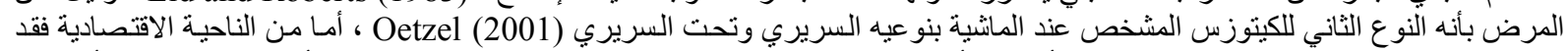

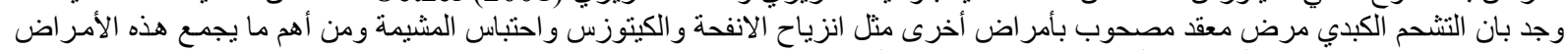

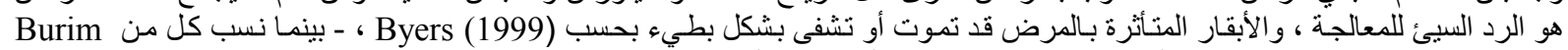

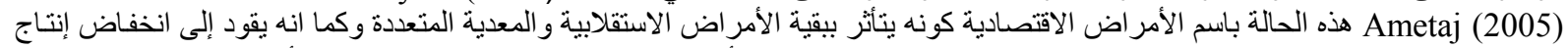

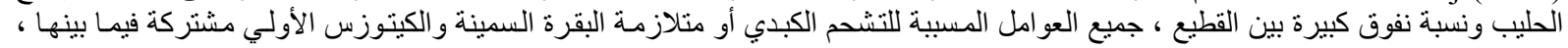

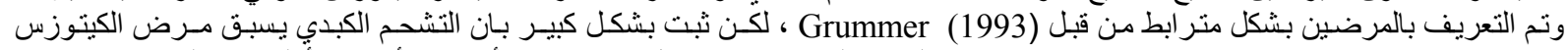

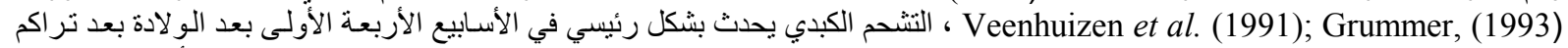

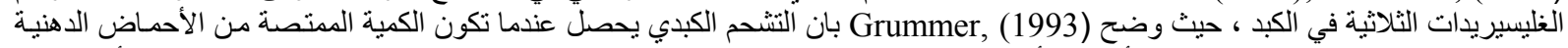

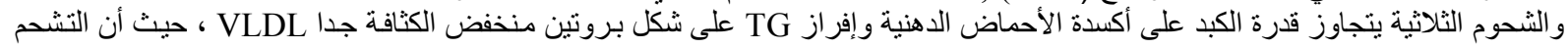

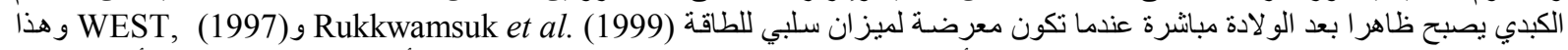

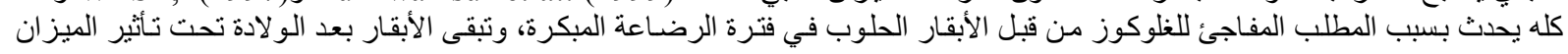




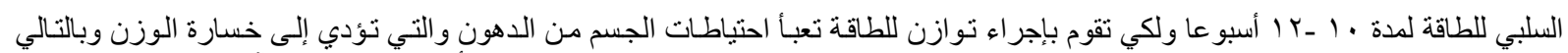

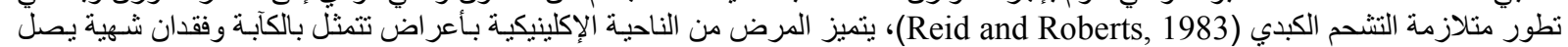

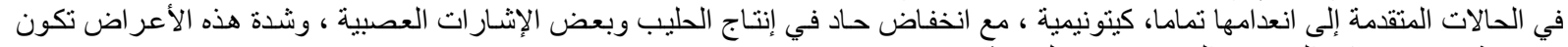

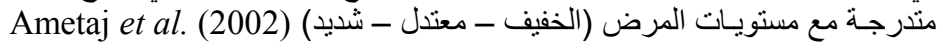

الأبقار المتأثرة بالمرض يكون منوفر فيها ظهور احد الأمر اض الاستقلابية أو أكثر ومن أهمها (كيتوزس ـ التهاب الضرع - انزيـاح الانفحة ـ

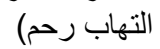

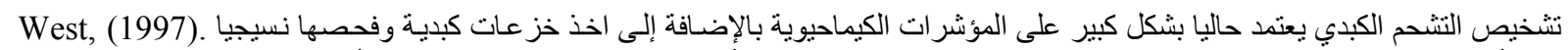

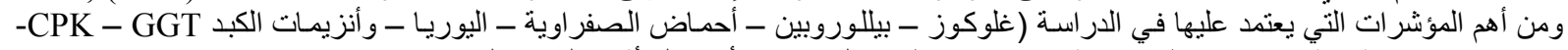

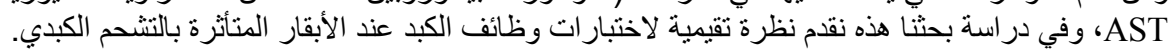

\section{MATERIALS and METHODS}

مواد وطرق البحث

حيوانات التجربة:

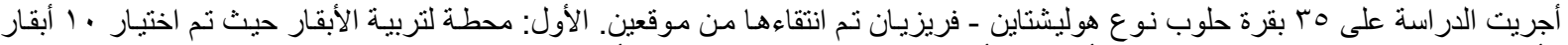

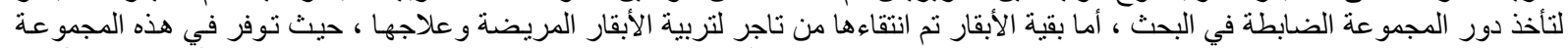

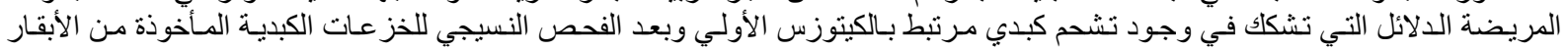

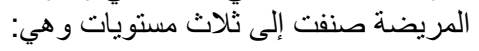

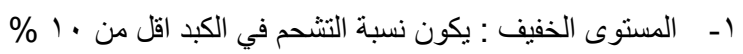

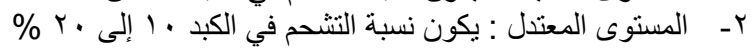

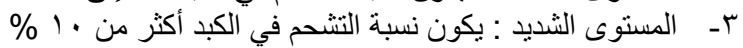

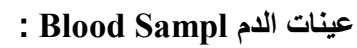

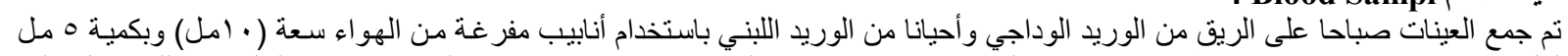

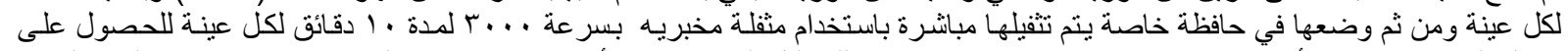

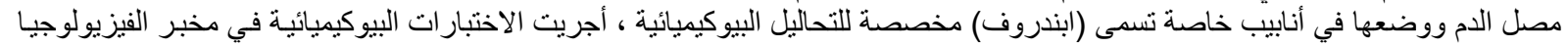

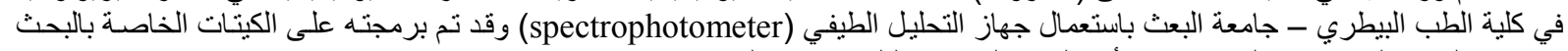

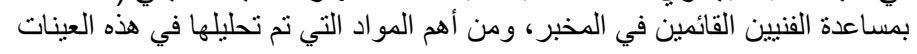

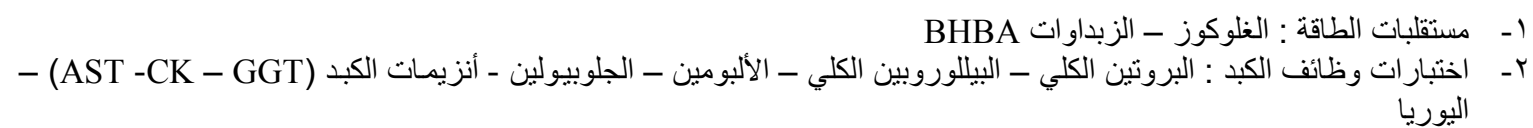

الخزعة الكبدية Liver Biopsy

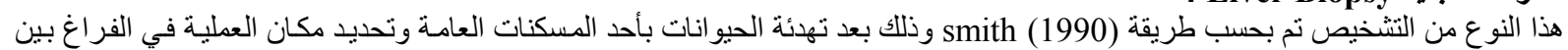

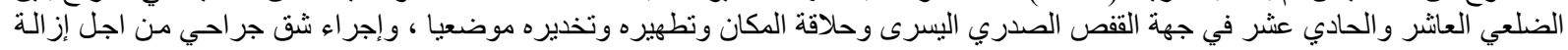

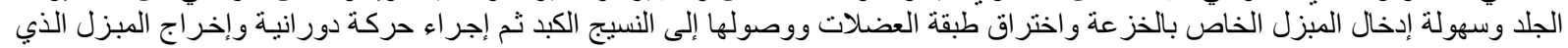

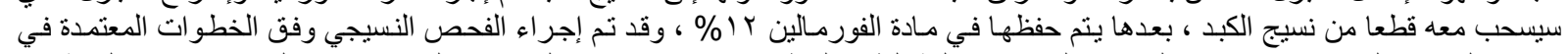

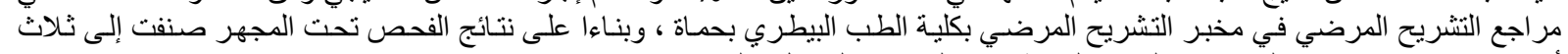

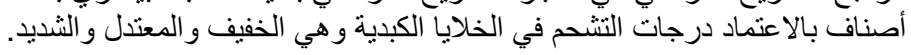

: Statistical Analysis الاراسة الإحصائية

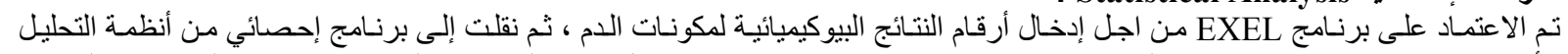

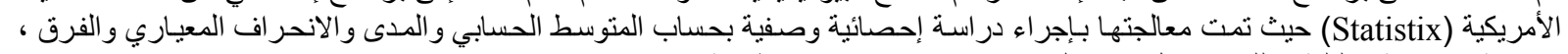

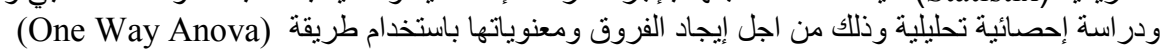

\section{RESULTS النتأسج}

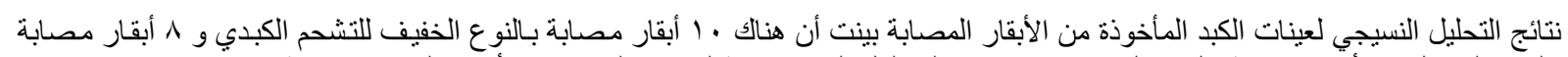

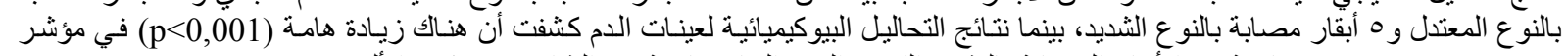

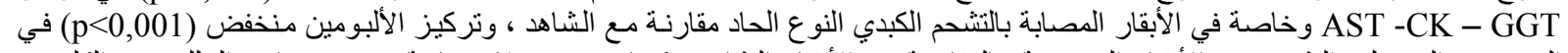

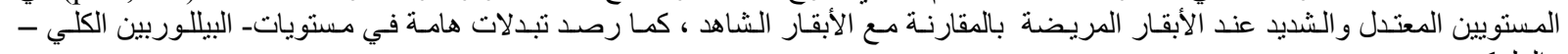

و الغلوكوز

\section{DISCUSSION and CONCLUSION المناقثة والخاتمة}




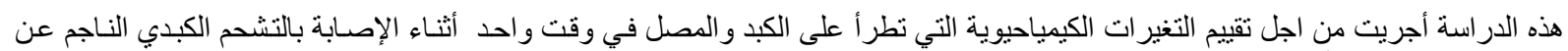
الإصابة بالكيتوزس الأولي ، و الربط بينهما من خلال تصنيف المرض الفير إلى ثلاثل مستويات (خفيف ـمعتدل ـ شديد)

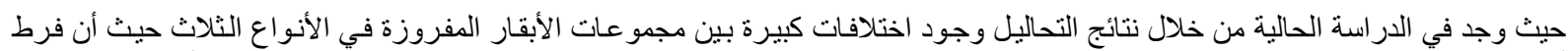

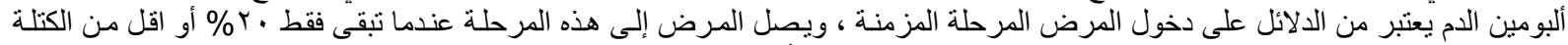

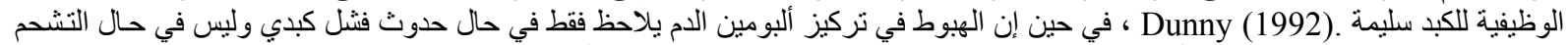

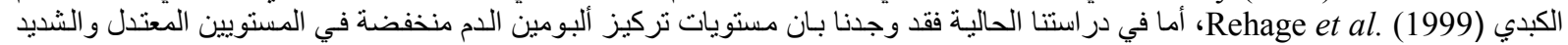

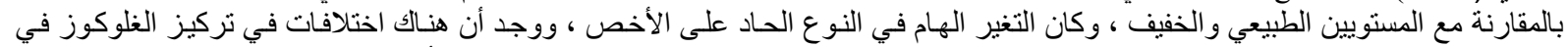

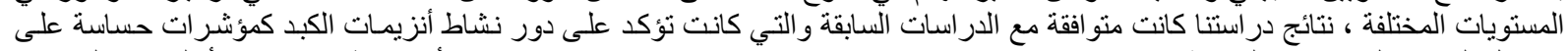

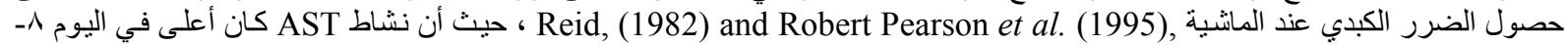

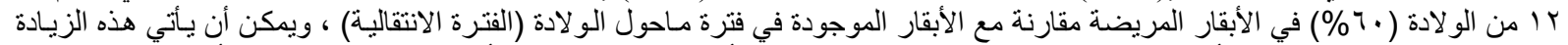

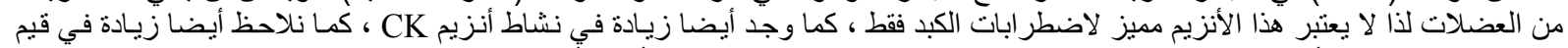

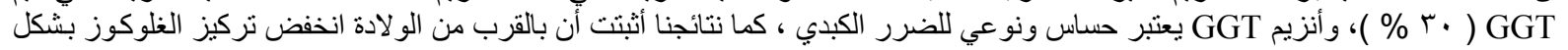

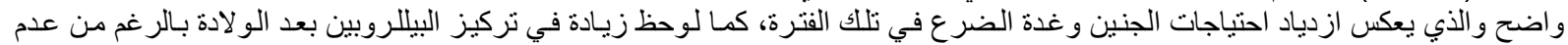

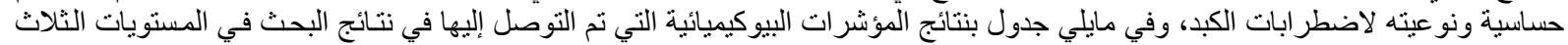
للتشحم الكبدي.

\begin{tabular}{|c|c|c|c|c|c|}
\hline $\mathrm{P}$ & الثديد & المعتدل & الخفيف & الثشاهد & المؤشر \\
\hline 0.000 & $53.7 \pm 4.0$ & $53.4 \pm 2.5$ & $58.8 \pm 5.6$ & $82.3 \pm 5.1$ & mg/dl الغلوكوز \\
\hline 0.001 & $1.02 \pm 0.02$ & $0.90 \pm 0.01$ & $0.89 \pm 0.02$ & $0.80 \pm 0.01$ & الزبداو ات mmol/1 \\
\hline 0.007 & $0.6 \pm 0.1$ & $0.5 \pm 0.1$ & $0.3 \pm 0.1$ & $0.3 \pm 0.1$ & البلليروبين الكلي mg/dl \\
\hline 0.005 & $7.7 \pm 0.2$ & $7.1 \pm 0.2$ & $8.1 \pm 0.2$ & $7.9 \pm 0.1$ & g/dl البروتين الكلي \\
\hline 0.000 & $2.1 \pm 0.1$ & $2.7 \pm 0.1$ & $3.3 \pm 0.1$ & $3.4 \pm 0.1$ & g/dl ألبومين الكلي \\
\hline 0.009 & $4.4 \pm 0.2$ & $3.8 \pm 0.3$ & $4.9 \pm 0.2$ & $4.5 \pm .1$ & جلوبيولين g/d1 \\
\hline 0.000 & $6.7 \pm 1.1$ & $43.7 \pm 7.5$ & $24.6 \pm 2.6$ & $22.3 \pm 2.1$ & GGT U/L \\
\hline 0.000 & $156.6 \pm 23$ & $96.0 \pm 6.7$ & $82.6 \pm 7.3$ & $65.1 \pm 4$ & AST U/L \\
\hline 0.011 & $228.4 \pm 4$ & $197.9 \pm 22$ & $112.2 \pm 9.6$ & $121.2 \pm 12.3$ & $\mathrm{CK} \mathrm{U/L}$ \\
\hline
\end{tabular}

و عند إجر اء معالجة تجريبية لبعض الأبقار الاختبار من خلال إخضاع عدد من الأبقار في كل مسنوى (خفيف ـ منوسط - شديد) لنظام غذائي

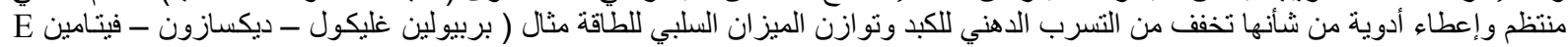

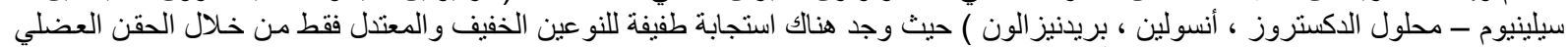

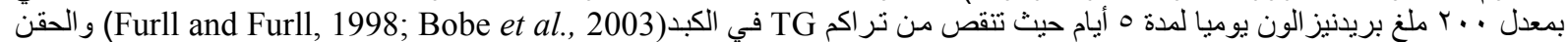

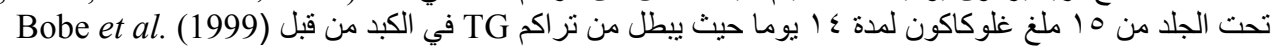

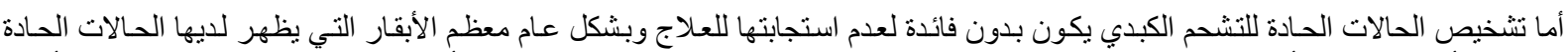

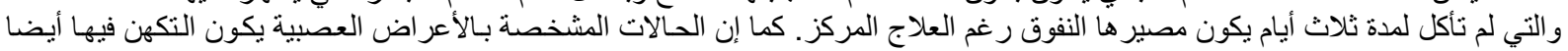

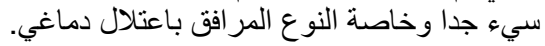

\section{REFERENCE المراجع}

Ametaj, B.N.; Bradford, B.J.; Bobe, G.; Lu, Y.; Nafikov, R.; Sonon, R.N.; Young, J.W. and Beitz, D.C. (2002): Acute phase response indicates inflammatory conditions may play a role in the pathogenesis of fatty liver in dairy cows. J. Dairy Sci. 85 (Suppl. 1): 189. (Abstr.) (26).

Bobe, G.; Amin, V.R.; Hippen, A.R.; Wilson, D.E.; Lindberg, G.L. and Young, J.W. (1999): Non-invasive determination of liver lipidcontent in dairy cows by digital analyses of ultrasonic images. J. Dairy Sci. 82(Suppl. 1): 100. (Abstr.)

Burim, N. Ametaj (2005): A New Understanding of the Causes of Fatty Liver in DairyCowsAdvances in Dairy Technology (2005) Volume 17, page 97.

Byers, D.I. (1999): Controlling metabolic diseasesTri-state dairy nutrition conference, April, 1-9.

dunn, Y. (1992): Assessment of liver damage and dyes function. In Practice., July, 193- 200.

FÜrll, M. and FÜrll, B. (1998): Glucocorticoid (prednisolone) effects on various blood, urine and liver parameters in cows in the secondpost partum week. Tieraerztl. Prax. Ausg. G Grosstiere Nutztiere 26:262-268. In German; abstract in English.

Grummer, R.R. (1993): Etiology of lipid related metabolic disorders in periparturient dairy cattle.J. Dairy Sci. 76: 3882-3896.

Oetzel, R.G. (2001): Ketosis and hepatic lipidosis in dairy herds.American Association of bovine practitioners 34th Annual convention, September 11-12. 
Pearson, EG.; Dirksen, G. and Meyer, J. (1995): Evaluation of liver function tests in neonatal calves. J Am Vet Med Assoc 1995; 1; 207 (11): 1466-9.

Rehage, J.; Quallmann, K.; Meien, C.; Stockhofe-zurviedenn. Hoeltenshinkan, M. and Pohlanz, J. (1999): Total serum bile acid concentration in dairy cows with fatty liver and liver failure. Dtsch. Tierarztl. Wschr., 106: 26-29.

Reid, I. and Robert, J. (1982): Fatty liver in dairy cows. In Practice 1982, 164-18.

Reid, IM. and Collins, RA. (1980): The pathology of postparturient fatty liver in high-yielding dairy cows. Invest Cell Pathol 1980; 3(3): 237-49.

Reid, IM. and Roberts, CJ. (1983): Subclinical fatty liver in dairy cows. Irish Vet. J., 1983, 37, 104.

Rukkwamsuk, T.; Kiuip, T.A.M. and Wensing, T. (1999): Relationshipbetween over feeding and over conditioning in the dairy periodand the problems of high producing dairy cows during the postparturientperiod. Vet. Quart., 1999, 21: 71-77.

Smith, P. Bradford (1990): Large animal internal medicineC.V. Mosby Company. Philadelphia, 1 st Ed.

Veenhuizen, J.J.; Drackley, J.K.; Richard, M.J.; Sanderson, T.P.; Miller, L.D. and Young, J.W. (1991): Metabolic changes in blood and liver during development and early treatment of expermintallyfatty liver and ketosis in cows.J. Dairy Sci., 74, 4238-4253.

West, H.J. (1997): Clinical and pathological studies in cattle with hepatic disease. Veterinary Research Commwticnrions, 21 (3), 169-185(28). 